\title{
Technical and Operational Innovations Approaches to Firm Performance of SMEs Auto Service Sector
}

\author{
Collins KanKam-Kwarteng \\ Kumasi Technical University. Ghana \\ John Gartchie Gatsi \\ School of Business \\ University of Cape Coast, Ghana \\ Stephen Acheampong \\ School of Business, \\ Ghana Baptist University College. Ghana \\ Jacob Donkor \\ School of Business, \\ Ghana Baptist University College. Ghana
}

\begin{abstract}
The purpose of this paper is to provide a framework to help SMEs auto service providers appreciate the critical contribution of innovations (technical and operational) to their performance. Specifically, the study examines the direct relationship between technical innovation and firm performance and the mediating role of operational innovation in the relationship. Participants of the study were drawn from the SMEs auto service providers in Kumasi, Ghana. Multiple regression analysis was performed to estimate the direct relationship and the mediating effects. In all, 180 questionnaires were used for the analysis after performing data screening. The results demonstrate that there is a statistically significant relationship between technical innovation and firm performance. Operational innovation was also found to mediate the relationship between technical innovation and firm performance. The study assumed that information regarding the operations of the participants is complete and that participants were selected based on willingness to participate. It is recommended for future researchers to explore other avenues of the subject matter to develop a standardised pattern of operations in the SMEs auto services sector.
\end{abstract}

\section{INTRODUCTION}

Previous studies on Small and Micro Enterprises (SMEs) services performance suggest a number of predictors. Management researchers have over the years investigated and compiled the critical factors that contribute to the outcome of the firm performance SMEs service sector with innovation capabilities as the predictors (see; Sarooghi et al.,2015; Atuahene-Gima, 2005) However, much research has not been conducted into the automobile services industry in Ghana (Kankam-Kwarteng \& Amoateng, 2016). The dimensionalities in measuring the performance of SMEs service firms have included both internal capabilities and external capabilities components of business operations (Singh et al., 2008). Significant, to the internal capabilities of the firm, include building continuous capabilities in innovations. KankamKwarteng et al. (2018) found that firm performance measurement in the SMEs auto service in Ghana can be attributed to service innovations. Walker (2004) suggests that types of innovation are critical in influencing each other and they should be instituted in conjunction to realise their full potential. On technical innovation, Staropoli (1998) found that it can be improved by accommodating institutional rearrangement and coordinating frameworks. 
Various types of innovations that have been posited by Walker (2004) are closely related and that the more research is required to provide further clarify their contribution towards building a comprehensive framework for measuring the effects of innovations on the performance of enterprises. The significant link between the performance of firms and innovations has been demonstrated in previous empirical research (see; Koc \& Ceylan, 2007; Li \& Atuahene-Gima, 2001). The theoretical literature relating to The Relationship between the innovations types have been limited (Gunday et al., 2011). All the types of innovation activities are expected to lead to superior firm performance compared to enterprises that are not innovation oriented. In measuring firm performance outcomes of SMEs service sector, different concepts have been used (Rosenbusch et al., 2011).

In most cases, the predictors have been based on internal capabilities such as innovation. In this study of the SMEs auto service industry, innovations of the firms have been conceptualised into technical and operational innovations and how they influence firm performance. This dimension is based on the nature of operations of the SMEs auto service industry.

\section{LITERATURE REVIEW}

Available literature on firm innovativeness maintains that innovation is one of the core elements for the success of firms and their survival (Jimenez \& Sanz-Valle, 2011; Cho \& Pucik, 2005; Bell, 2005; Damanpour, 1996; Fiol, 1996; Wolfe, 1994) and sustainable competitiveness (Standing \& Kiniti, 2011; Bartel \& Garud, 2009; Johannessen, 2008; Mumford \& Licuanan, 2004). Even with the dimensionalities of the concepts of innovations in extant literature, management researchers continue to struggle for a consensus standard of the exact meaning of the concept (Amara \& Landry, 2005). Therrien et al. (2011) posited that innovation involves innovativeness capabilities transform complex processes that relate to changes in process and production functions in which enterprises seek to formulate and implement their unique competencies in technology, considered as a set of resources an enterprise possesses and the manner in these.

Innovation at the firms' level refers to an enterprise' receptivity and propensity to adopt new ideas that lead to the development and launch of a new service (Rubera and Kirca, 2012). According to Brouwer (2000) innovations can be categorised into two primary forms, a process and product innovations. Innovation researchers have suggested business model innovations, managerial innovations, organisational innovations and marketing innovations (see; Subramaniam \& Youndt, 2005; McGrath, 2001; Huiban \& Bouhsina, 1998). Firm innovativeness is also characterised by incremental and radical, based on its degree (Koberg et al., 2003). Some management researchers also categorised innovations covering product and processes types from non-technological innovation capturing organisational and marketing innovations.

The current research is based on the categorisation of two types of innovations conceptualisation from the existing models of innovations found in the extant literature (see; Damanpour et al., 2009; Popadiuk, \& Choo, 2006) as technical innovation and operational innovation. Technical innovation introduces a new service or significantly transformed services based on its characteristics and intended uses (Rice, 2013; Tether, 2005). They included significant transformations in technical components and materials, specifications, user-friendliness, incorporated software and other functional attributes (Sanz-Valle et al., 2011). The operational innovation of firms has to do with introducing customer specific requirements that are considered marketing oriented. Thus, operational innovation of the firm is the formulation of an innovative marketing strategy consisting of significant transformation 
in service package, service design, placement of service, service pricing and service promotion (Klingenberg et al., 2013). Operational innovation aims at an effective way of addressing the needs of customers, opening a new market, positioning the firms' service on the market with the intention of improving customer base (Oke \& Kach, 2012).

\section{Firm performance and Innovation}

The Resource-Based Theory (RBT) of the firm suggests that enterprises have a bundle of capabilities and resources. These capabilities and resources provide a more sustainable competitive advantage and contribute to higher returns (Peteraf \& Barney, 2003). Resources consist of enterprises' intangible and tangible human resources, and capabilities refer to the ability of an enterprise to make full use of these resources (Harrison et al., 2010). Management researchers (see; Molloy et al., 2011; Ray et al., 2005) have conceptualized an enterprise resources as the resources that involves the capabilities, assets, firm attributes, organizational processes, knowledge and information structured by the firm that enables the business to formulate and implement a strategy that increase its effectiveness and efficiency. Innovation capabilities based on technical and operational orientations are resources that enhance organisational competitiveness (Zhou et al., 2005). The practical application of innovative capabilities is widely recognised in contemporary management practices as a tool for providing a sustained competitive advantage resulting in enhanced the performance of the enterprise (Koc \& Ceylan, 2007).

Firm performance has been considered in the literature as a multidimensional concept (Poon et al., 2006; Murphy et al., 1996; Venkatraman \& Ramanujam, 1986) involving components that can be categorised into finance, production and marketing (Sohn et al., 2007). The determinants of firm performance have been extensive in the literature (Donkor et al., 2018). Fundamental to performance studies have been on innovation capabilities (Camisón \& VillarLópez, 2014). The implementation of innovation strategies as a predictor of firm performance has been studied extensively. However, the existing research on innovation is yet to provide consistency evidence on the effects of the new dimension as proposed in this study (technical innovation and operational innovation) on the performance of SMEs (Koc \& Ceylan, 2007; Li and Atuahene-Gima, 2001). There is empirical support for the broad innovation influence on firm performance (Prajogo, 2006). Notably, some researchers have found either no direct effect of innovation on performance (Wang et al., 2011) or a negative effect (Kotabe et al., 2002). Barker III and Mueller (2002) explained that R\&D investment and implementation could have either a negative or positive impact on profitability in various situations. Such a conflicting outcome is an indication that the innovation and firm performance relationship is more complicated than assumed (Baer \& Frese, 2003). Based on the dimensionalities in the innovation firm performance and the proposed conceptualisation of the innovation into technical and operational, this study hypothesised that;

H1: Technical innovation will have a significant positive influence on firm performance SMEs auto service industry

H2: Operational Innovation will have a significant positive impact on firm performance SMEs auto service industry

H3: Operational innovation will mediate the Technical innovation and firm performance SMEs auto service industry

\section{Population and sampling issues}

\section{METHODOLOGY}

The study focused on the SMEs auto service firms in Ghana. Data were obtained from a sample of 180 auto service sector SMEs in Kumasi through the administering of questionnaires. The participants were selected based on the principle of willingness to participate. It became 
necessary to the non-probability sample techniques (Convenience) because of the difficulty in controlling the entire population of the SMEs auto service operator to perform a probability or random procedures. The questionnaires were filled by SMEs owners and operations of the service centres of the businesses. The questionnaire included firm-specific characteristics which included firm age, Firm size and ownership types. The items for technical innovation, operational innovation and firm performance were developed based on measurement scales.

\section{Measures}

In this paper, innovations are categorised as technical service innovation and operational service innovation. The items developed for the two variables were extracted from existing types of innovations including process, product, organisational and marketing innovations. For the activities of the SMEs auto service industry, the items were refined to suit the technical demands of service automobiles and the activities aimed at increasing customer management (operational innovation). The initial items were technical innovation (11-items) and operational innovation (9-items). After reliability and validity test of the measuring scale, four4 items each were retained for both technical innovation and operational innovation. All the scales for both technical innovation and operational innovation were measured on a Likert scale ' 5 ' strongly agree to ' 1 ' strongly disagree.

Firm performance has been measured from different perspectives. Two most prominent perspectives included subjective measures and objective measures (Wall et al., 2004; Dawes, 1999; Dess \& Robinson, 1984). Firm performance measures chosen for this study are subjective. This is because there is the difficulty in collected objective data based on financial statements from the SMEs auto service industry. Venkatraman (1989) explains that in the absence of any objective data that is publicly available subjective data becomes a perfect replacement. Four 4-items were retained for firm performance after screening 11 items across areas of financial and operational performance. All the scales for firm performance were measured on a Likert scale ' 5 ' strongly agree to 1 strongly disagree.

\section{Firm profile}

\section{ANALYSIS OF RESULTS}

Table 1 reports the sampled firm characteristics. It is noted that the most of the sampled firms $(55.5 \%)$ are sole proprietorships. It should be emphasised that the study endeavoured to capture firms of all types including joint ventures (12\%), partnerships $(22.5 \%)$ and others including sole proprietorships (10\%). The majority of these institutions were identified to be micro and small-scale enterprises (70\%) as compared to medium scale institutions (20\%). Concerning the number of years of existence, the report indicates that whiles majority of the firms are within 10 years (76\%). It is also demonstrated that the number of firms declines as the number of years extends; suggesting somewhat remotely the inability of most SMEs to operate for extended periods. 
Table I: Firm Profile

\begin{tabular}{|l|l|c|c|}
\hline \multicolumn{2}{|c|}{} & Frequency & Per cent \\
\hline \multirow{4}{*}{ Business Type } & Sole proprietorship & 100 & 56 \\
\cline { 2 - 4 } & Partnership & 41 & 23 \\
\cline { 2 - 4 } & Joint venture & 22 & 12 \\
\cline { 2 - 4 } & Others & 18 & 10 \\
\cline { 2 - 4 } & Total & 180 & 100 \\
\hline \multirow{5}{*}{ Firm age } & Up to 2 years & 31 & 17 \\
\cline { 2 - 4 } & From 2-5 & 65 & 36 \\
\cline { 2 - 4 } & From 5-9 & 41 & 23 \\
\cline { 2 - 4 } & From 9-13 & 27 & 15 \\
\cline { 2 - 4 } & From 13 and above & 16 & 9 \\
\cline { 2 - 4 } & Total & 180 & 70 \\
\hline \multirow{3}{*}{ Firm Size } & $5-9$ employees & 126 & 30 \\
\cline { 2 - 4 } & $10+$ employees & 54 & 100 \\
\cline { 2 - 4 } & Total & 180 & 100 \\
\hline
\end{tabular}

Source: Authors (2018)

\section{Reliability and validity}

After data collection, a series of analyses were performed to test the reliability and validity of the constructs. The researchers followed a two-step method to test the construct reliability. First, the researchers conducted exploratory factor (EFA) analyses using both orthogonal and oblique rotations to ensure high loadings on hypothesised factors and low loadings on crossloadings in the data sets. All the items loaded onto the expected factors without significant cross-loadings. Then the reliability of each construct was tested using Cronbach's alpha. Cronbach's values shown in Table 3 are within the acceptable values for all constructs dataset indicating that all constructs are reliable for this research.

Table II: Construct reliability and Validity

\begin{tabular}{|c|c|c|}
\hline Constructs & $\begin{array}{l}\text { Factor } \\
\text { Loading }\end{array}$ & Alpha $(\alpha)$ \\
\hline \multicolumn{3}{|c|}{ Technical Innovation (KMO=0.806, Variance explained $=42.396 \%$, Alpha $=0.829$ ) } \\
\hline 1. Using skills and systems to respond quickly to auto services & 0.741 & 0.799 \\
\hline $\begin{array}{l}\text { 2. Acquire relevant technology in response to advances in auto } \\
\text { servicing }\end{array}$ & 0.652 & 0.811 \\
\hline $\begin{array}{l}\text { 3. The industry is in constant needs of technical skills and } \\
\text { supports systems }\end{array}$ & 0.553 & 0.822 \\
\hline $\begin{array}{l}\text { 4. There are significant transformations in technical components } \\
\text { and materials used for auto servicing }\end{array}$ & 0.662 & 0.811 \\
\hline \multicolumn{3}{|c|}{ Operational Innovation $(\mathrm{KMO}=0.729$, Variance explained $=54.420 \%$, Alpha $=0.710$} \\
\hline 1. We have been consistent in meeting the needs of customers & 0.755 & 0.613 \\
\hline $\begin{array}{l}\text { 2. The extent of varieties of services offered to customers is } \\
\text { incomparable }\end{array}$ & 0.645 & 0.708 \\
\hline $\begin{array}{l}\text { 3. The nature of service support to customers are constantly } \\
\text { improving }\end{array}$ & 0.794 & 0.616 \\
\hline $\begin{array}{l}\text { 4. } \begin{array}{l}\text { Customers are constantly consulted in providing service } \\
\text { delivery }\end{array} \\
\end{array}$ & 0.748 & 0.656 \\
\hline \multicolumn{3}{|c|}{ Firm Performance (F. P)(KMO=.710, Variance explained=59.044\%, Alpha=0.765) } \\
\hline 1. SMEs auto services growth & 0.714 & 0.747 \\
\hline 2. High profitability in the auto servicing business & 0.698 & 0.752 \\
\hline 3. Increased market share in servicing automobiles & 0.844 & 0.648 \\
\hline 4. Competitive advantage gained in auto services & 0.808 & 0.682 \\
\hline
\end{tabular}

Source: Authors' Survey, 2018 
Factor loadings and Cranach's alpha of Technical innovation, Operational innovation and firm performance have been produced individually and are shown in Table II. Technical innovation contained four-4 items showing Cronbach's alpha of 0.829. Total variance explained is 42.396\%, and Kaiser-Meyer-Olkin (KMO) stands to be 0.806. Operational innovation containing four-4 items explained $54.42 \%$ of total variance and alpha stood to be at 0.710 . Finally, firm performance contained four-4 items and explained 59.044\% variance. KMO remained at 0.710 and alpha stood to be at 0.765 .

\section{Correlation Analysis and Descriptive Statistics}

Kamasak (2011) asserts that a low to moderate correlation among the explanatory variables is needed to ensure that they contribute distinctly and uniquely to the overall model. As indicated in Table III, the correlation between the independent variables is less than 0.9 indicating there isn't the likelihood of multicollinearity occurring in the model. Again, Table III indicates that there's a positive and significant association between technical innovation and firm performance ( $\mathrm{r}=.487, \mathrm{P}<5 \%$ ). The conclusion is that an improvement in SMEs technical skills and efforts corresponds to an enhancement in firm performance in the SMEs auto service sector. Similarly, a significant and positive relationship was found between technical innovation and operational innovation $(\mathrm{r}=.546, \mathrm{P}<5 \%)$. This indicates that SMEs with higher capabilities in innovations perform better than rivals. Meanwhile a significant and positive relationship was found between operational innovation and firm performance $(\mathrm{r}=0.349, \mathrm{P}<$ $5 \%$ ). The implication is that an improvement in SMEs which applies stronger operational innovations is also more inclined to enjoy the higher firm performance.

Table III. Correlation Analysis and Descriptive Statistics

\begin{tabular}{|l|c|c|c|c|c|}
\hline Variables & Mean & S.D. & $\begin{array}{c}\text { Technical } \\
\text { Innovation }\end{array}$ & $\begin{array}{c}\text { Operational } \\
\text { Innovation }\end{array}$ & $\begin{array}{c}\text { Firm } \\
\text { Performance }\end{array}$ \\
\hline Technical Innovation & 4.12 & 0.55 & 1.00 & & \\
\hline Operational Innovation & 3.66 & 0.61 & 0.546 & 1.00 & \\
\hline Firm Performance & 3.99 & 0.77 & 0.478 & 0.349 & 1.00 \\
\hline
\end{tabular}

Source: Authors' Survey, 2018

Regarding the level and scope of activities, a descriptive summary of the variables indicates that averagely, the level of technical innovation of the sampled firms is high (Mean $=4.12 ; \mathrm{SD}=$ 0.55). This means that the average SME is very likely to build a strong form of technical skills in providing services. It was however observed the level of operational innovations (Mean = 3.66; $\mathrm{SD}=0.61$ ) is moderate. An averagely moderately high level of performance was also identified among the sampled SMEs in the auto service sector (Mean $=3.99$; SD $=0.77$ ).

\section{Regression Analysis}

A structural equation modelling was developed to estimate the relationship between technical innovation, operational innovation and firm performance. Specifically, the researchers try to ascertain whether operational innovation performed any mediating role in the relationship between technical innovation and firm performance. The results of the mediating analysis are presented in Table 5. The model fitness of the structural model shows that partial mediation yielded superior performance over the alternative of full mediation. For the partial mediation the model fitness test results obtained are $\chi^{2}$ (d.f) $=13.841(6), \operatorname{RMSEA}=0.07, \mathrm{CFI}=0.98$, SRMR $=0.02$; whereas the fitness statistics obtained for the full mediation model are: $\chi^{2}$ (d.f) $=$ 
47.760 (5), RMSEA $=0.11, \mathrm{CFI}=0.94, \mathrm{SRMR}=0.04$. The chi-square difference test shows that there is a significant difference between the two models $\left(\Delta \chi^{2}=33.92 \Delta \text { d.f }=1, p<0.05\right)^{1}$. The information parsimony statistics also confirmed that the partial mediation model was superior. The estimates of the partial mediation are, therefore, interpreted.

In examining the standard estimates of the partial mediation model, therefore, it is observed that the direct paths from technical innovation $(\beta=0.347 ; p<0.05)$ to operational innovation was positive and significant. Moreover, the results showed that there is also a positive and significant relationship between operation innovation and firm performance $(\beta=0.243 ; p$ $<0.05)$. The implication is that building a strong operational innovation in the area of operation is also vital for accruing superior performance among operators in SMEs auto service industry. This, therefore, emphasises the need for small and medium scale enterprises to commit themselves to the implementation of competitive strategies to remain innovation oriented in the market. The results also demonstrate a significant and positive relationship between technical innovation and firm performance $(\beta=0.444 ; p<0.05)$. This is indicative of the fact that the deployment of innovation capabilities is also vital for organisations to perform better. Concerning the mediating role of operational innovation, the results revealed that operational innovation mediated the relationship between technical innovation and firm performance $(\beta=0.097 ; p<0.10)$.

Table IV: Standardized Estimates and Model Fit

\begin{tabular}{|l|c|c|}
\hline Variables & Full Mediation & Partial Mediation \\
\hline & Beta (S.E) & Beta (S.E) \\
\hline Firm Performance & & \\
\hline Technical Innovation & -- & $0.444(.077)^{* * *}$ \\
\hline Operational Innovation & $.279(.096)^{* * *}$ & $0.243(.103)^{* *}$ \\
\hline & & \\
\hline Operational Innovation $\leftarrow$ & & \\
\hline Technical Innovation & $.347(.117)^{* *}$ & $0.347(.117)^{* *}$ \\
\hline & & \\
\hline Indirect Effect & $.097(.047)^{* *}$ & $.097(.046)^{*}$ \\
\hline Technical Innovation & & \\
\hline & & 13.841 \\
\hline Fit Indices & 47.760 & 6 \\
\hline$\chi 2$ & 5 & 0.07 \\
\hline d.f & 0.112 & 0.98 \\
\hline RMSEA & 0.94 & 0.02 \\
\hline CFI & 0.04 & 4506.34 \\
\hline$S R M R$ & 6880.16 & 4548.42 \\
\hline AIC & 6928.86 & \\
\hline$B I C$ & Survey, 2018 & \\
\hline
\end{tabular}

Source: Authors' Survey, 2018

\section{DISCUSSION OF RESULTS}

Service innovation capabilities in firms are suggested by many management researchers to contribute to SMEs firm performance. More recently, some studies empirically discussed the effects of service innovation on various aspects of firm performance. However, few research studies link technical service innovation, operational service innovation and SMEs performance from a holistic perspective. More significantly, a study that specifically addresses SMEs auto services industry. By proposing a model discussing the effects of technical 
innovation and operational innovation which in turn lead to both financial and operational performance of SMEs auto services sector, the findings contribute to filling the gap in the literature. The empirical results of this research confirm the stated hypothesis: technical innovation on firm performance, operational innovation on firm performance and the mediating effects of operational innovation on technical innovation and firm performance relationship. This finding is consistent with the work of Li and Atuahene-Gima (2001) who also established that innovations have a direct, positive impact on organisational performance. This finding is consistent with the innovation capability based theories which suggest that the acquisition of innovation capabilities can be a source of improving the performance of businesses (see; Gronum et al., 2012). Through effects analysis, this research provides a possible framework for innovation capabilities (technical and operational) practices lead to superior firm performance. The mediator role of operational innovations is also confirmed. Thus, operational innovation contributes directly to and indirectly to firm performance. Compared with the available literature, the research has not only been conceptualised the linkages between innovation and firm performance, but also a more specific detail of technical innovation and operational innovation. Significantly, the model proposed in this study might be applied as an alternative model for theoretically evaluating innovation and SMEs performance in future studies.

Interestingly the findings of this work demonstrate that whiles technical innovation can impact on firm performance directly, it also has an indirect effect on performance through its capacity of engaging firms to improve their operational capabilities. The implication is that SMEs can potential develops capabilities in innovations whiles focusing on both technical and operational innovations.

\section{PRACTICAL IMPLICATIONS}

This study has practical implications. The relationships between technical service innovations and operational innovations and firm performance may provide a framework as to how organisations should achieve superior performance by implementing technical service innovation and operational service innovations. Scales designed in this study offer a checklist for SMEs service providers to assess themselves in a certain environment.

SMEs service operators should think over the important antecedents that lead to the technical service innovation and operational innovation in improving their performance levels.

Furthermore, strategies and activities for technical innovation and operational innovation should be formulated for various firm performances. Future researchers, therefore, need to give broader considerations to the strategies and implementation of programs supporting these activities to improve firm performance.

\section{LIMITATIONS AND FUTURE STUDIES}

This study has limitations. First, potential lack of generalisation may result from the application of willingness to participate used to select SMEs auto service providers. Second, the use of cross-sectional data did not allow longitudinal research processes of the conceptual framework measured in this research. Third, though the study results empirically confirmed the hypothesis model, it was rather simple and incorporated a few constructs. It is important to note that there is an opportunity to expand the model to incorporate other consequent and antecedent constructs such as firm-specific attributes to form a more comprehensive model linking technical service innovation and operational service innovation. As a suggestion for further improvement, we need to note the importance of the sustainability of firm performance 
generated in technical service innovation and operational service innovation capabilities. Longitudinal samples gathered based on multiple points of time can help support this research objective.

Nevertheless, this survey has produced empirically based evidence to substantiate the hypothesised associations that both technical service innovation and operational service innovation will contribute to firm performance directly or through the improvement of the mediated effort of operational innovation. Technical service innovation has more significant effects on firm performance than the effort of operational innovation. The findings are encouraged to bring more insight into how firms SMEs auto service industry should enhance their performance with well-conceived technical service innovation and operational innovation strategies and practices.

\section{References}

Amara, N. and Landry, R. (2005). Sources of information as determinants of novelty of innovation in manufacturing firms: evidence from the 1999 statistics Canada innovation survey. Technovation, 25(3), pp.245259.

Atuahene-Gima, K., 2005. Resolving the capability_rigidity paradox in new product innovation. Journal of marketing, 69(4), pp.61-83.

Baer, M., \& Frese, M.(2003). Innovation is not enough: Climates for initiative and psychological safety, process innovations, and firm performance. Journal of Organizational Behavior: The International Journal of Industrial, Occupational and Organizational Psychology and Behavior, 24(1), 45-68.

Barker III, V.L. and Mueller, G.C. (2002). CEO characteristics and firm R\&D spending. Management Science, 48(6), pp.782-801.

Bartel, C.A. and Garud, R. (2009). The role of narratives in sustaining organizational innovation. Organization science, 20(1), pp.107-117.

Bell, G.G. (2005). Clusters, networks, and firm innovativeness. Strategic management journal, 26(3), pp.287-295.

Brouwer, M. (2000). Entrepreneurship and uncertainty: innovation and competition among the many. Small Business Economics, 15(2), pp.149-160.

Camisón, C. and Villar-López, A. (2014). Organizational innovation as an enabler of technological innovation capabilities and firm performance. Journal of business research, 67(1), pp.2891-2902.

Cho, H.J. and Pucik, V. (2005). Relationship between innovativeness, quality, growth, profitability, and market value. Strategic management journal, 26(6), pp.555-575.

Damanpour, F. (1996). Organizational complexity and innovation: developing and testing multiple contingency models. Management Science, 42(5), pp.693-716.

Damanpour, F., Walker, R.M. and Avellaneda, C.N. (2009). Combinative effects of innovation types and organizational performance: A longitudinal study of service organizations. Journal of management studies, 46(4), pp.650-675.

Dawes, J. (1999). The relationship between subjective and objective company performance measures in market orientation research: further empirical evidence. Marketing bulletin-department of marketing massey university, $10,65-75$.

Dess, G. G., \& Robinson Jr, R. B. (1984). Measuring organizational performance in the absence of objective measures: the case of the privately-held firm and conglomerate business unit. Strategic management journal, 5(3), 265-273.

Donkor, J., Donkor, G. N. A., \& Kankam-Kwarteng, C. (2018). Strategic planning and performance of SMEs in Ghana: The moderating effect of market dynamism. Asia Pacific Journal of Innovation and Entrepreneurship, 12(1), 62-76.

Fiol, C.M. (1996). Squeezing harder doesn't always work: Continuing the search for consistency in innovation research. Academy of Management Review, 21(4), pp.1012-1021.

Gronum, S., Verreynne, M. L., \& Kastelle, T. (2012). The role of networks in small and medium-sized enterprise innovation and firm performance. Journal of Small Business Management, 50(2), 257-282. 
Gunday, G., Ulusoy, G., Kilic, K. and Alpkan, L. (2011). Effects of innovation types on firm performance. International Journal of production economics, 133(2), pp.662-676.

Harrison, J.S., Bosse, D.A. and Phillips, R.A. (2010). Managing for stakeholders, stakeholder utility functions, and competitive advantage. Strategic management journal, 31(1), pp.58-74.

Huiban, J.P. and Bouhsina, Z. (1998). Innovation and the quality of labour factor: an empirical investigation in the French food industry. Small Business Economics, 10(4), pp.389-400.

Jiménez-Jiménez, D. and Sanz-Valle, R. (2011). Innovation, organizational learning, and performance. Journal of business research, 64(4), pp.408-417.

Johannessen, J.A. (2008). Organisational innovation as part of knowledge management. International Journal of Information Management, 28(5), pp.403-412.

Kankam-Kwarteng, C. and Amoateng, F. (2016). Servicescape And Customers' Willingness-To-Pay For Vehicle Repairs And Maintenance Services. European Scientific Journal, ESJ, 12(10).

KanKam-Kwarteng, C., Gatsi, J. G., Donkor, J., \& Acheampong, S. (2018). Service Innovation and Firm Performance of SMEs auto service: the mediating role of Pricing Capability. Archives of Business Research, 6(8), 39-50.

Klingenberg, B., Timberlake, R., Geurts, T.G. and Brown, R.J. (2013). The relationship of operational innovation and financial performance-A critical perspective. International Journal of Production Economics, 142(2), pp.317-323.

Koberg, C.S., Detienne, D.R. and Heppard, K.A. (2003). An empirical test of environmental, organizational, and process factors affecting incremental and radical innovation. The Journal of High Technology Management Research, 14(1), pp.21-45.

Kotabe, M., Srinivasan, S. S., \& Aulakh, P. S. (2002). Multinationality and firm performance: The moderating role of R\&D and marketing capabilities. Journal of international business studies, 33(1), 79-97.

Li, H. and Atuahene-Gima, K. (2001). Product innovation strategy and the performance of new technology ventures in China. Academy of management Journal, 44(6), pp.1123-1134.

McGrath, R.G. (2001). Exploratory learning, innovative capacity, and managerial oversight. Academy of management journal, 44(1), pp.118-131.

Molloy, J.C., Chadwick, C., Ployhart, R.E. and Golden, S.J. (2011). Making intangibles "tangible" in tests of resourcebased theory: A multidisciplinary construct validation approach. Journal of Management, 37(5), pp.1496-1518.

Mumford, M.D. and Licuanan, B. (2004). Leading for innovation: Conclusions, issues, and directions. The leadership quarterly, 15(1), pp.163-171.

Oke, A. and Kach, A. (2012). Linking sourcing and collaborative strategies to financial performance: The role of operational innovation. Journal of Purchasing and Supply Management, 18(1), pp.46-59.

Popadiuk, S. and Choo, C.W. (2006). Innovation and knowledge creation: How are these concepts related?. International journal of information management, 26(4), pp.302-312.

Peteraf, M.A. and Barney, J.B. (2003). Unraveling the resource-based tangle. Managerial and decision economics, 24(4), pp.309-323.

Poon, J.M., Ainuddin, R.A. and Junit, S.O.H. (2006). Effects of self-concept traits and entrepreneurial orientation on firm performance. International small business journal, 24(1), pp.61-82.

Prajogo, D. I., \& Ahmed, P. K. (2006). Relationships between innovation stimulus, innovation capacity, and innovation performance. R\&D Management, 36(5), 499-515.

Ray, G., Muhanna, W.A. and Barney, J.B. (2005). Information technology and the performance of the customer service process: A resource-based analysis. MIS quarterly, pp.625-652.

Rosenbusch, N., Brinckmann, J. and Bausch, A. (2011). Is innovation always beneficial? A meta-analysis of the relationship between innovation and performance in SMEs. Journal of business Venturing, 26(4), pp.441-457.

Rice, A.K. (2013). Productivity and social organization: The Ahmedabad experiment: Technical innovation, work organization and management. Routledge.

Rubera, G. and Kirca, A.H. (2012). Firm innovativeness and its performance outcomes: A meta-analytic review and theoretical integration. Journal of Marketing, 76(3), pp.130-147. 
Sanz-Valle, R., Naranjo-Valencia, J.C., Jiménez-Jiménez, D. and Perez-Caballero, L., 2011. Linking organizational learning with technical innovation and organizational culture. Journal of Knowledge Management, 15(6), pp.9971015.

Sarooghi, H., Libaers, D. and Burkemper, A., 2015. Examining the relationship between creativity and innovation: A meta-analysis of organizational, cultural, and environmental factors. Journal of business venturing, 30(5), pp.714-731.

Singh, R.K., Garg, S.K. and Deshmukh, S.G. (2008). Strategy development by SMEs for competitiveness: a review. Benchmarking: An International Journal, 15(5), pp.525-547.

Sohn, S. Y., Kim, H. S., \& Moon, T. H. (2007). Predicting the financial performance index of technology fund for SME using structural equation model. Expert Systems with Applications, 32(3), 890-898.

Standing, C. and Kiniti, S. (2011). How can organizations use wikis for innovation?. Technovation, 31(7), pp.287295.

Staropoli, C. (1998). Cooperation in R\&D in the pharmaceutical industry-the network as an organizational innovation governing technological innovation. Technovation, 18(1), pp.13-23.

Subramaniam, M. and Youndt, M.A. (2005). The influence of intellectual capital on the types of innovative capabilities. Academy of Management Journal, 48(3), pp.450-463.

Tether, B.S. (2005). Do services innovate (differently)? Insights from the European innobarometer survey. Industry \& Innovation, 12(2), pp.153-184.

Therrien, P., Doloreux, D. and Chamberlin, T. (2011). Innovation novelty and (commercial) performance in the service sector: A Canadian firm-level analysis. Technovation, 31(12), pp.655-665.

Koc, T. and Ceylan, C. (2007). Factors impacting the innovative capacity in large-scale companies. Technovation, 27(3), pp.105-114.

Venkatraman, N. and Ramanujam, V. (1986). Measurement of business performance in strategy research: A comparison of approaches. Academy of management review, 11(4), pp.801-814.

Wall, T. D., Michie, J., Patterson, M., Wood, S. J., Sheehan, M., Clegg, C. W., \& West, M. (2004). On the validity of subjective measures of company performance. Personnel Psychology, 57(1), 95-118.

Walker, R. M., (2004). Innovation and Organisational Performance: Evidence and a Research Agenda (June 2, 2004). Advanced Institute of Management Research Paper No. 002. Available at SSRN:

http://dx.doi.org/10.2139/ssrn.1306909

Wang, L., Yeung, J. H. Y., \& Zhang, M. (2011). The impact of trust and contract on innovation performance: The moderating role of environmental uncertainty. International Journal of Production Economics, 134(1), $114-122$.

Wolfe, R.A. (1994). Organizational innovation: Review, critique and suggested research directions. Journal of management studies, 31(3), pp.405-431.

Zhou, K.Z., Yim, C.K. and Tse, D.K. (2005). The effects of strategic orientations on technology-and market-based breakthrough innovations. Journal of marketing, 69(2), pp.42-60. 